Summary-A rapid photometric titration titration technique, which makes it possible to determine methylmercuric ions with a sensitivity of $15 \mu \mathrm{g}$, is described. The titration takes place in $80 \%$ aqueous ethanol, which is capable of dissolving the titrant, a chloroform solution of dithizone. It has thus been possible to avoid the difficulties arising from co-extraction phenomena that occur when the extractive titration procedures developed for mercury(II) are applied to the determination of methylmercuric ions. A formate buffer is used to keep the $\mathrm{pH}$ in the range 2.5-3.0. The attainable precision is considerably better than $1 \%$.

Zusammenfassung-Ein schnelles photometrisches Titrationsverfahren wird beschrieben, das die Bestimmung von Methylquecksilber(II)-Ionen mit einer Empfindlichkeit von $15 \mu \mathrm{g}$ ermöglicht. Die Titration wird in $80 \%$ wäßrigem Äthanol ausgeführt; darin löst sich der Titrant, eine Chloroformlösung von Dithizon. Auf diese Weise konnten die Schwierigkeiten überwunden werden, die sich bei der Bestimmung von Methylquecksilber(II)-Ionen mit den für Quecksilber(II) entwickelten extraktiven Titrationsverfahren durch Mitextraktions-Erscheinungen ergaben. Ein Formiatpuffer dient dazu, den pH im Bereich 2,5-3,0 zu halten. Man kann erhebl ich bessere Genauigkeiten als $1 \%$ erhalten.

Résumé-On décrit une technique de titrage photométrique rapide, qui rend possible le dosage des ions méthylmercuriques avec une sensibilité de $15 \mu \mathrm{g}$. Le titrage se fait en éthanol aqueux à $80 \%$, qui est capable de dissoudre l'agent de titrage, une solution chloroformique de dithizone. Il a été ainsi possible d'éviter les difficultés provenant des phénomènes de co-extraction qui se produisent lorsque les techniques de titrage par extraction élaborées pour le mercure(II) sont appliquées au dosage des ions méthylmercuriques. On utilise un tampon formiate pour maintenir le pH dans le domaine 2,5-3,0. La précision que l'on peut atteindre est de beaucoup meilleure que $1 \%$.

\title{
REFERENCES
}

1. J. C. Gage, Analyst, 1961, 86, 457.

2. H. M. N. H. Irving and J. J. Cox, J. Chem. Soc., 1963, 466.

3. Idem, ibid., 1961, 1470.

4. H. M. N. H. Irving and A. M. Kiwan, Anal. Chim. Acta, 1969, 45, 243.

5. G. Iwantscheff, Das Dithizon. Verlag Chemie, Weinheim, 1958.

6. I. M. Kolthoff and Philip J. Elving, eds., Treatise on Analytical Chemistry. Wiley/Interscience, New York, 1961.

7. A. Ringbom, Complexation in Analytical Chemistry. Wiley/Interscience, New York, 1963.

Talanta, 1971, Vol. 18, pp. 747 to 751. Pereamon Press. Printed in Northern Ireland

\section{Extractive spectrophotometric determination of micro and sub-micro amounts of fluoride}

\author{
(Received 2 June 1970. Accepted 16 November 1970)
}

SPECTROPHOTOMETRIC fluoride determinations, based on the direct reaction between fiuoride and the cerium(III) or lanthanum(III) chelate of alizarin complexan (3-[di(carboxymethyl)aminomethyl]1,2-dihydroxyanthraquinone) are often used. The first was introduced by Leonard and West. ${ }^{1}$ Other workers proved that the addition of an organic solvent enhanced the sensitivity and the 
stability of the complexes. In this manner Yamamura et ai.. and Greenhalgh and Riley, used acetone or acetonitrile, while Hanocq and Molle advised dimethylsulphoxide. All these determinations were described only for the range of $5-25 \mu \mathrm{g}$ of fluoride in a sample volume of $10-75 \mathrm{ml}$. For lower amounts, such as 0.1-1 $\mu \mathrm{g}$ of fluoride in a sample volume of $2 \mathrm{ml}$, procedures involving solvent extraction and subsequent colorometric measurement were developed by Hall, and Cox and Backer Dirks. ${ }^{6}$ A method for concentrations of 0.25-7 $\mu \mathrm{g}$ of fluoride in $150 \mathrm{ml}$ of water was published by Johnson and Leonard. ${ }^{7}$ Procedures of a similar nature are described by Hirano et al. ${ }^{8}$ and by Daries and Foreman."

In the present paper, a simple, sensitive extractive determination with a low blank is investigated, which can be used for concentrations of $0.1-1 \mu \mathrm{g}$ of fluoride in $4 \mathrm{ml}$ of water and 5-25 $\mu \mathrm{g}$ of fluoride in $90 \mathrm{ml}$ of water.

\section{EXPERIMENTAL}

\section{Reagents}

Alizarin complexan $\left(1.25 \times 10^{-8} \mathrm{M}\right)$-pH 4.3 buffer mixture. Dissolve $263.3 \mathrm{mg}$ of alizarin complexan dihydrate and $10.5 \mathrm{~g}$ of hydrated sodium acetate in $350 \mathrm{ml}$ of water. Adjust the $\mathrm{pH}$ with glacial acetic acid potentiometrically. Transfer the solution to a $500-\mathrm{ml}$ standard flask and make up to the mark with water. The solution is stable for a considerable length of time.

Cerium(III) nitrate, $1.375 \times 10^{-8} \mathrm{M}$. Dissolve $303.1 \mathrm{mg}$ of cerium(III) nitrate $\left[\mathrm{Ce}\left(\mathrm{NO}_{3}\right)_{3} \cdot 6 \mathrm{H}_{2} \mathrm{O}\right.$, purity $98.5 \%$ in water to make $500 \mathrm{ml}$ of solution.

Stock fluoride solution, $100 \mu \mathrm{g} / \mathrm{ml}$. Dissolve $221.1 \mathrm{mg}$ of pure sodium fluoride in water and dilute to 1 litre. Store in a polythene container.

Standard fuoride solutions, $1 \mu \mathrm{g} / \mathrm{ml}$ and $0.5 \mu \mathrm{g} / \mathrm{ml}$. Dilute 10- $\mathrm{ml}$ portions of the stock fluoride solution to 1 or 21 . Store in polythene containers. The standard fluoride solutions should be freshly prepared every week.

Buffer solution pH 9. Dissolve $77.1 \mathrm{~g}$ of ammonium acetate in $350 \mathrm{ml}$ of water and add $10 \mathrm{ml}$ of $8 M$ ammonia solution. Adjust the $\mathrm{pH}$ with ammonia potentiometrically and dilute to $500 \mathrm{ml}$ with water.

Extracting solvent, $5 \% \mathrm{v} / \mathrm{v}$ triethylamine in n-pentanol. Dilute $25 \mathrm{ml}$ of triethylamine with $\mathrm{n}$ pentanol to $500 \mathrm{ml}$.

\section{Preparation of the standard curves}

Procedure I for 0.1-1 $\mu \mathrm{g}$ of fluoride (sample volume $4 \mathrm{ml}$ ). In 100-ml standard flasks take $0,5,10$, $20,30,40$ and $50 \mathrm{ml}$ of $0.5 \mu \mathrm{g} / \mathrm{ml}$ standard fluoride solution and make up to the mark with water. These solutions contain respectively $0,0.1,0.2,0.4,0.6,0.8$ and $1.0 \mu \mathrm{g}$ of luoride per $4 \mathrm{ml}$. In stoppered 10-ml tubes take $4 \mathrm{ml}$ of fluoride solution, $0.5 \mathrm{ml}$ of the alizarin complexan-buffer mixture and $0.5 \mathrm{ml}$ of cerium(III) nitrate solution and mix well. After $1 \mathrm{hr}$ add $0.5 \mathrm{ml}$ of extraction solvent and $0.5 \mathrm{ml}$ of $\mathrm{pH} 9$ buffer and immediately shake for $2 \mathrm{~min}$. Allow to stand for $10 \mathrm{~min}$. Transfer the organic layer to a microcentrifuge tube and centrifuge for $2 \min (4000 \mathrm{rpm})$. Transfer the extract to a $10-\mathrm{mm}$ cell (narrow enough to be filled by $0.2 \mathrm{ml}$ of solution) and measure the absorbance at 570 $\mathrm{nm}$ against water as reference.

Procedure II for 5-25 $\mu \mathrm{g}$ of fluoride (sample volume $90 \mathrm{ml}$ ). In 100-ml calibrated flasks take 0,5 , $10,15,20$ and $25 \mathrm{ml}$ of $1 \mu \mathrm{g} / \mathrm{ml}$ standard fuoride solution. Dilute to approximately $80 \mathrm{ml}$ and add 5 $\mathrm{ml}$ of alizarin complexan-buffer mixture and $5 \mathrm{ml}$ of cerium(III) nitrate solution. Dilute to volume and mix. After $1 \mathrm{hr}$ pour the solution into a $250-\mathrm{ml}$ separating funnel, add $10 \mathrm{ml}$ of extracting solvent and $10 \mathrm{ml}$ of $\mathrm{pH} 9$ buffer and immediately shake for $2 \mathrm{~min}$. Allow to stand for $10 \mathrm{~min}$. Transfer the organic layer into a centrifuge tube, and centrifuge for $2 \min (4000 \mathrm{rpm})$. Transfer the extract into a $10-\mathrm{mm}$ cell and measure the absorbance at $570 \mathrm{~nm}$ against water as reference.

\section{RESULTS AND DISCUSSION}

\section{Callbration curves}

The calibration curves are linear up to 1.5 and $40 \mu \mathrm{g}$ of fluoride for Procedures I and II respectively except for a slight curvature at the lowest concentrations $(0-0.2 \mu \mathrm{g}$ of fluoride for Procedure $I$ and $0-5 \mu \mathrm{g}$ for Procedure II) but in practice this presents no problem. For Procedure II the reproducibility for the blank and a $25-\mu \mathrm{g}$ fluoride sample was checked by repeating the experiment 10 times during a period of a fortnight. The mean absorbances were 0.024 with standard deviation $s=0.002$ for the blank and 0.416 with $s=0.0035$ (corresponding to $0.2 \mu \mathrm{g}$ of fluoride) for the sample. The absorbance is stable (within \pm 0.003 ) for at least $24 \mathrm{hr}$.

\section{Extraction with different volumes of solvent}

Procedure II was used but there were some differences during development of the method. Initially, $10 \mathrm{ml}$ each of the alizarin complexan-buffer mixture and the cerium(III) nitrate solution 
were used and no $\mathrm{pH} 9$ buffer was used during the extraction. Before and after extraction the $\mathrm{pH}$ of the aqueous phase was measured, and the $\mathrm{pH}$ after extraction was taken as the $\mathrm{pH}$ during extraction. The results are shown in Fig. 1. The dotted line refers to the absorbance, without extraction, of the aqueous phase at $610 \mathrm{~nm}$, in a $10-\mathrm{mm}$ cell against water as reference. Extraction with solvent volume ratio of $1: 1$ gives a sharp reduction in the blank value, while the sensitivity is about equal. This procedure provides a means of nearly completely separating the fluoride complex from the cerium(III)alizarin complexan chelate. At other volume ratios, the blank value and sensitivity increase, a ratio of $1: 10$ being the optimum.

Further experiments showed that at constant volume-ratio absorbance was strongly dependent on the $\mathrm{pH}$. As a consequence, the $\mathrm{pH}$ during extraction must be kept constant. It was also found that slight variations (even \pm 0.1 ) of the $\mathrm{pH}$ before the extraction gave rise to large variations of the $\mathrm{pH}$ during extraction. For these reasons a pH 9 buffer was added before extraction. Other experiments showed that with extraction with a volume ratio 1:10 the final concentrations of alizarin complexan and cerium(III) nitrate could be reduced to $6.25 \times 10^{-5} M$ and $6.875 \times 10^{-6} M$ respectively as in Procedure II. The result was that the blank was halved without loss of sensitivity.

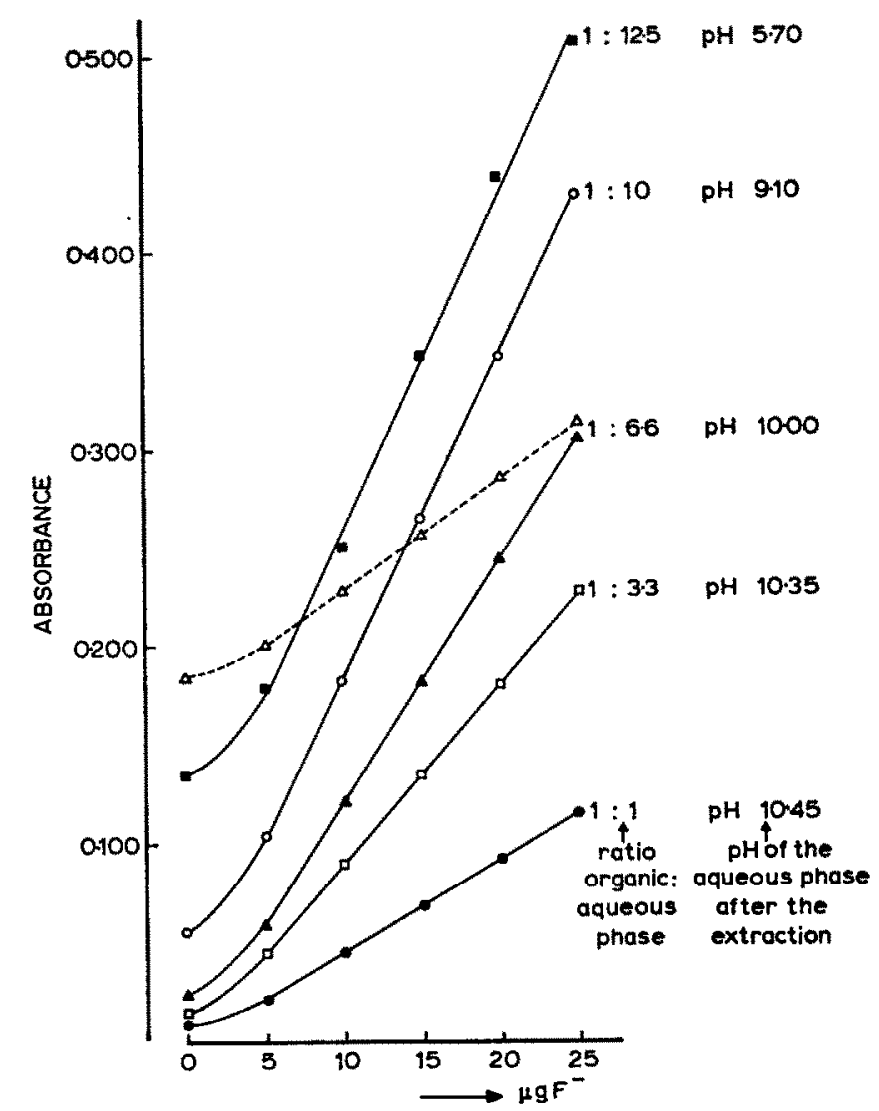

Fro. 1. Extraction with different volumes of extractant.

Dotted line: Absorbance of the aqueous phase before extraction, measured at $610 \mathrm{~nm}$ in a $10-\mathrm{mm}$ cell against water as reference.

\section{Effect of temperature}

It is found that between 15 and $25^{\circ}$ the absorbance increases with temperature at the rate of $0.001 / \mathrm{deg}$ for the blank and $0.002 / \mathrm{deg}$ for $25 \mu \mathrm{g}$ of fluoride. 
Interferences

Some results are shown in Table $I$ and are in agreement with those of other workers. Presumably certain interferences are inevitable.

TABLE I.-INTERFERENCE OF IONS IN THE DETERMINATION OF $25 \mu \mathrm{g}$ OF FLUORIDE

\begin{tabular}{|c|c|c|c|c|}
\hline Ion & Added as & [Ion]/[F-] & Absorbance & Difference caused $\%$ \\
\hline none & & & $0.416^{*}$ & \\
\hline \multirow{2}{*}{$\mathrm{SO}_{4}{ }^{2-}$} & $\mathrm{Na}_{2} \mathrm{SO}_{4}$ & 25 & 0.422 & +1.4 \\
\hline & & 100 & 0.400 & $-3 \cdot 8$ \\
\hline \multirow[t]{2}{*}{$\mathrm{Cl}^{-}$} & $\mathrm{NaCl}$ & 250 & 0.416 & 0.0 \\
\hline & & 1000 & 0.413 & -0.7 \\
\hline \multirow[t]{4}{*}{$\mathrm{HCO}_{3}^{--}$} & $\mathrm{NaHCO}_{3}$ & 25 & 0.428 & +2.9 \\
\hline & & 250 & 0.457 & +9.9 \\
\hline & & 1000 & 0.474 & +13.9 \\
\hline & & $1000 \dagger$ & 0.399 & $-4 \cdot 1$ \\
\hline \multirow[t]{2}{*}{$\mathrm{NO}_{3}^{-}$} & $\mathrm{NaNO}_{3}$ & 500 & 0.405 & $-2 \cdot 6$ \\
\hline & & 2000 & 0.360 & $-13 \cdot 6$ \\
\hline $\mathrm{PO}_{4}^{3-}$ & $\mathrm{KH}_{2} \mathrm{PO}_{4}$ & 1 & 0.394 & $-5 \cdot 3$ \\
\hline $\mathrm{Al}^{3+}$ & $\mathrm{Al}_{2}\left(\mathrm{SO}_{4}\right)_{3}$ & 1 & 0.370 & $-11 \cdot 1$ \\
\hline $\mathrm{Fe}^{3+}$ & $\mathrm{Fe}\left(\mathrm{NO}_{3}\right)_{3}$ & 1 & 0.428 & $+2 \cdot 9$ \\
\hline
\end{tabular}

* The mean of 10 separate determinations, accumulated over a period of a fortnight, standard deviation $\mathbf{0 . 0 0 3 5}$.

$\dagger$ Before colour development glacial acetic acid was first added to make the $\mathrm{pH}$ of the solution approximately 5 , and then the solution was boiled.

\section{CONCLUSION}

The results obtained compare favourably with others reported for microgram and submicrogram determinations of fluoride. For determination of 5-25 $\mu \mathrm{g}$ of fluoride the extraction procedure involves more work than the non-extractive procedures do, but the low blank, greater sensitivity and good accuracy cancel this disadvantage. The method described here is less sensitive than the method of Johnson and Leonard, ${ }^{7}$ but the latter has a much higher value for the absorbance of the blank $(0.339, s=0.007)$. The great feature of this work is the low blank value $(0.024, s=0.002)$, obtained with a simple procedure, albeit at the expense of sensitivity. The determination of $0 \cdot 1-1 \mu \mathrm{g}$ of fluoride proposed here is simpler than those published by Hall ${ }^{5}$ and by Cox and Backer Dirks, ${ }^{8}$ and has about twice the sensitivity.

Analytisch Chemisch Laboratorium of the State University Croesestraat 77 A, Utrecht, The Netherlands

J. P. S. HaArsma

J. Agterdenbos

Summary-A simple and sensitive extractive spectrophotometric determination of fluoride with the cerium(III)-alizarin complexan chelate has been investigated. The fluoro chelate formed is extracted into n-pentanol containing triethylamine. It is possible to achieve under selected conditions a selective extraction of the cerium(III)alizarin complexan-fluoride chelate. The stability of the chelate, the effect of temperature and the low absorbance of the blank are discussed. It is found that it is necessary to add a pH 9 buffer before the extraction. Procedures are given for the determination of 0.1-1 $\mu \mathrm{g}$ of fluoride in a 4-ml sample and 5-25 $\mu \mathrm{g}$ of fluoride in a 90-ml sample.

Zusammenfassung - Ein einfaches und empfindliches extraktivspektrophotometrisches Verfahren zur Bestimmung von Fluorid mit dem Chelat aus Cer(III) und Alizarincomplexan wurde untersucht. Das gebildete Fluorochelat wird in Triäthylamin enthaltendes $n$-Pentanol extrahiert. Unter geeigneten Bedingungen ist eine selektive Extraktion des Chelats aus Cer(III), Alizarincomplexan und Fluorid zu erreichen. Die Stabilität des Chelats, der EinfluB der Temperatur und die geringe Extinktion der Blindlösung werden diskutiert. Vor der Extraktion muß ein pH 9-Puffer zugesetzt werden. Vorschriften zur Bestimmung von 0,1-1 $\mu \mathrm{g}$ Fluorid in einer $4 \mathrm{ml}-$ Probe und von 5-25 $\mu \mathrm{g}$ Fluorid in einer $90 \mathrm{ml}$-Probe werden angegeben. 
Résumé-On a étudié une méthode de dosage spectrophotométrique par extraction, simple et sensible, du fluor avec le chélate cérium(III)alizarine complexan. Le fluorochélate formé est extrait en n-pentanol contenant de la triéthylamine. Il est possible de réaliser dans des conditions choisies une extraction sélective du chélate cérium(III)alizarine complexan-fluorure. On discute de la stabilité du chélate, de l'influence de la température et de la faible absorption du témoin. On a trouvé qu'il est nécessaire d'ajouter un tampon pH 9 avant l'extraction. On donne des techniques pour le dosage de $0,1-1 \mu \mathrm{g}$ de fluorure dans un échantillon de $4 \mathrm{ml}$ et de 5-25 $\mu \mathrm{g}$ de fluorure dans un échantillon de $90 \mathrm{ml}$.

\section{REFERENCES}

1. M. A. Leonard and T. S. West, J. Chem. Soc., 1960, 4477.

2. S. S. Yamamura, M. A. Wade and J. H. Sikes, Anal. Chem., 1962, 34, 1308.

3. R. Greenhalgh and J P. Riley, Anal. Chim. Acta, 1961, 25, 179.

4. M. Hanocq and L. Molle, ibid., 1968, 42, 349.

5. R. J. Hall, Analyst, 1963, 88, 76.

6. F. H. Cox and O. Backer Dirks, Caries Res., 1968, 2, 69.

7. C. A. Johnson and M. A. Leonard, J. Pharm. Pharmacol., 1961, 13, 164T.

8. S. Hirano, H. Fujinuma and T. Kasai, Bunseki Kagaku, 1966, 15, 1339.

9. A. G. Daries and J. K. Foreman, Proc. S.A.C. Conf. Nottingham, 1965, 167. 